\title{
Forensic Accounting Knowledge and Mindset on Task Performance Fraud Risk Assessment
}

\author{
Oluwatoyin Muse Johnson Popoola ${ }^{1}$, Ayoib Che Ahmad ${ }^{1} \&$ Rose Shamsiah Samsudin ${ }^{1}$ \\ ${ }^{1}$ College of Business, School of Accountancy, Universiti Utara Malaysia, Malaysia \\ Correspondence: Oluwatoyin Muse Johnson Popoola, College of Business, School of Accountancy, Universiti \\ Utara Malaysia. Sintok 06010, Darul Aman, Kedah, Malaysia. Tel: 601-6435-4874. E-mail: \\ omjp0658@gmail.com
}

Received: July 2, 2014

doi:10.5539/ijbm.v9n9p118

\author{
Accepted: July 24, 2014 \\ Online Published: August 22, 2014 \\ URL: http://dx.doi.org/10.5539/ijbm.v9n9p118
}

\begin{abstract}
The paper investigates the relationship between knowledge (KR) and mindset (MR) on task performance fraud risk assessment (TPFRA) of forensic accountant and auditor in the public sector environment. It also examines the claim that forensic accountants possess higher level of KR, MR and TPFRA than auditors. The study design is cross-sectional. Survey questionnaire is used. The 300 respondents are real professional people (i.e., auditors and accountants in the Nigerian public sector) as true representatives to enhance the generalisation of the outcomes. PLS-SEM and IBM SPSS Statistics 20.0 were used as the primary statistical analysis tools for the study. The results of the present study confirm the positive relationship of KR and MR on TPFRA. Specifically, the results revealed that forensic accountants have higher levels of KR, MR and TPFRA than auditors in the areas of fraud prevention/deterrent, detection and response. Because of the adoption of cross-sectional design in which data are collected at one point of time, there is no time to wait for different follow-up stages or interventions before data analysis. Researchers are encouraged to use longitudinal design to explore interactions between KR, MR and TPFRA. This empirical study has revealed the value of KR and MR (forensic accountant and auditor) as a significant capability requirement in the workplace. Since no nation is immune to fraud and as loss due to fraud is costly, the result of this research will improve the corporate governance and accountability practices among public sector accountants and auditors.
\end{abstract}

Keywords: forensic accounting, auditing, knowledge, mindset, task performance fraud risk assessment, public sector

\section{Introduction}

The global environment necessitates a great impact on the controls and procedures to be established by forensic accountants and auditors in the conduct of the examination to detect, prevent and respond to fraud. The approach adopted by both the internal auditors to plan and complete task and the statutory independent auditors to assess fraud risk and audits revolve around the perception of the users of financial statements and the auditing and accounting standard setters. Furthermore, the technique adopted by the forensic accountants depend on the nature, scope, evidence gathering, skills requirement, limitation to use of the report and users of services and reports, amongst others.

Similarly, studies have shown that the frequency of accounting fraud, financial crimes and audit failures had a grave impact on the economy and causes a loss of stakeholders' confidence in the auditing profession (Hogan et al., 2008; Silverstone \& Davia, 2005). Houck et al. (2006) assert that fraud and forensic accounting affect the accounting profession every day.

In the Nigerian public sector, the growth in occupational fraud, money laundering, embezzlement, the concealment of debt, the concealment of assets, terrorism financing, corruptions, illegal or unethical acts and other financial crimes are the critical factors of gap, thus creating a niche to encourage investigation on the influence of the forensic accountant knowledge and mindset and auditor knowledge and mindset to improve transparency and accountability with an emphasis on accountants and auditors in the public sector of Nigeria.

Consequent upon the global meltdown that was as a result of the collapse of Enron, WorldCom, Parmalat (Doering, 2002), Accounting standard setters all over the world, especially in Nigeria and USA responded to the 
public outcry and issued Nigerian Standards on Auditing (NSA) No. 5, The Auditor's Responsibility to consider Fraud in an Audit of Financial Statements and Statement on Auditing Standards (SAS) No. 99, Consideration of fraud in a Financial Statement Audit (AICPA, Professional Standards, vol. 1, AU section. 316.50), the successor to (SAS) No. 82, Consideration of Fraud in a Financial Statement Audit (ICAN, 2005; AICPA, 2002).

Previous study confirms AICPA's (2002) guidance as having the potentials to improve audit quality in detecting material financial misstatements, whether caused by fraud or error. This standard contains the suggestion that the "auditor may respond to an identified risk of material misstatement due to fraud by assigning the forensic or IT specialists" (Popoola et al., 2013b; Wuerges, 2011; Chui, 2010; AICPA, 2002). Prior research describes three key risk factors related to fraud. These are incentive or pressures to commit fraud, the opportunity to carry out the fraud, and attitude or ability to rationalize the fraudulent action.

Furthermore, Wolfe and Hermanson (2004) argue the inclusion of "capability" as one of the elements of fraud. Therefore, there are currently four elements comprising incentive, opportunity, rationalization and capability. Consequently, these four elements are being referred to as "the fraud diamond theory." The first three elements as theorized by Cressey (1953; 1950) include: (1) incentive/pressure; (2) opportunity; and (3) attitude/rationalization. This is commonly referred to as "the fraud triangle theory," which was consequently adopted by the auditing profession (AICPA, 2002) and another unique element referred to as "capability." Wolfe and Hermanson's (2004) made it clear that fraudsters must have the fraud related knowledge and mindsets in order to commit fraud by observing the available opportunity and identifying weaknesses in the internal control, and, therefore, turn it into reality.

The theory of the fraud triangle by Cressey $(1953,1950)$ originated from Sutherland (1949) and Wolfe and Hermanson (2004) fraud diamond theory raised public awareness of fraud and forensic accounting. It emphasizes the importance of ensuring that public sector accountants have the required forensic accounting knowledge and mindset to detect, prevent, deter and respond to fraud using fraud risk assessment to improve task performance. Hence, forensic accountants will continue to be in high demand on one hand (Wells, 2005) as long as criminals exist in the areas of fraud, white collar crime, corruption, money laundering, terrorism financing, computer fraud, asset misappropriation and conversion, theft, and tax fraud. The authors agreed with Wells (2005) that as long as untrained graduates are used to detect fraud committed by technologically advanced perpetrators, the need for forensic accountants with fraud knowledge and mindset will continue to be on the increase.

\subsection{Research Questions}

1). Do knowledge and mindset requirements of forensic accountants and auditors relate to task performance fraud risk assessment?

2). Do forensic accountants have higher levels of knowledge, mindset and task performance fraud risk assessment requirements than auditors?

\subsection{Research Objectives}

In the light of the above research questions, the following objectives arise:

1). To examine the relationship between knowledge and mindset of forensic accountants and auditors, and task performance fraud risk assessment.

2). To explore whether forensic accountants possess higher levels of knowledge, mindset and task performance fraud risk assessment requirements than auditors.

\section{Review of Literature}

The public outcry portends an indication that the traditional accounting and auditing systems have failed to address and improve significantly accountability and transparency challenges in the public governance of Nigeria. Because corrupt and fraudulent practices increases at an alarming rate while public services, infrastructure and facilities are fast deteriorating (Civil Liberty Organisation (CLO), 2012; This Day Newspaper, November 23 and 25, 2012; The Punch, November 26, 2012; Leadership, November 26, 2012; Campaign for Democracy (CD), 2011).

Nigeria, as one of the developing nations, got independence from the British colonial masters in 1960. The country is well blessed in terms of resources such as human resources, natural resources (solid minerals, oil, hydroelectric energy, and water), agriculture, and good climate conditions. Despite the availability of these resources in abundance, the rate of economic development appears potentially weak, human capital development and provision of services; infrastructure and facilities are not adequate and sufficient. This slow pace of growth may be attributed to the high level of fraud, corruption, misappropriation and conversion of government 
properties, greed and mal-administration. As a result, most of the citizens migrate to other countries in the world in search of better opportunities such as economic and social empowerment, and sustainability.

Prior research conducted by the National fraud authority annual fraud indicator (2011) in United Kingdom indicates that the losses attributed to fraud are usually higher in the public sector in comparison with all other sectors (the private sector, not for profit organizations, and individuals) put together. For example, the National Fraud Authority, Annual Fraud (NFAAFI), UK in its study, "Fighting fraud together: the strategic plan to reduce fraud" identifies public sector fraud and financial crimes in 2011 to have constituted the highest loss of £21.2 billion $(55 \%)$ out of $£ 38.4$ billion. Other areas include private sector $£ 12$ billion $(31 \%)$, individual $£ 4$ billion (11\%), and charity organizations $£ 1.2(3 \%)$, (NFAAFI, 2011). Figure 1 illustrates the pie chart attributed to loss due to fraud in the United Kingdom, 2011.

Public sector has at various times been defined as "all organizations which are not privately owned and operated, but which are established, run and financed by the Government on behalf of the public (Hassan, 2001; Daniel, 1996). In essence, the public sector comprises organizations which are under the control of the public, as against private ownerships (Bammeke, 2008; Adams, 2004). The objective of public sector involves the provision of services, where profit is not a primary reason. However, performance measurement in the public sector is complicated by the lack of profit motive and presence ofintangible services whose benefits are difficult to quantify (ICAN, 2009).

Forensic accounting refers to anything from the execution of a fraud analysis to the recreation of "real" accounting records after the discovery that they have been manipulated. Boleigha (2011) noted that forensic accounting is not "accounting for dead people," rather it is the application of a broad range of accounting, auditing, and investigative skills to measure and verify economic damages and resolve financial disputes. Popoola et al., (2013b) defines forensic accounting as the integration of specialized accounting knowledge and positive mental attitude to resolve legal issues. Forensic accountants exist mainly for the same reasons why prosecutors and commercial branch investigators exist. This is due to the presence and manifestation of criminals in the areas of fraud, white collar crime, corruption, money laundering, computer fraud, and theft.

On the other hand, auditing is described as an unbiased examination and evaluation of the financial statements of an organization to expedite expression of opinion on its truth and fairness (Adebisi, 2011). It can be done internally (by employees of the organization) or externally (by an independent professional firm). The International Standards on Auditing No. 700 provides "the objective of the audit of financial statements is to enable the auditor to express an opinion whether the financial statements are prepared, in all material respects, in accordance with the applicable financial reporting framework." The authors recommended that for clarity purposes, ISA 700 should be read in conjunction with ISA 200, "overall objectives of the Independent auditor and the Conduct of an audit in accordance with International Standards on Auditing." Therefore, an audit of financial statements is an assurance engagement as defined in the International Framework for Assurance Engagements (2006), which is meant to enhance the degree of confidence of the intended users (IFAC ISA 200, section 1, para 3, p. 72).

Several researchers describe fraud as "a means by which a person can achieve an advantage over another by false suggestions or suppression of the truth" (Keshi, 2011; Bellovary, 2006; Singleton et al., 2006). The term "fraud" refers to an intentional act by one or more individuals among management, those charged with governance, employees, or third parties, involving the use of deception to obtain an unjust or illegal advantage. According to ISA No. 700 and ISA 200, management fraud relates to a situation where fraud involves one or more members of management or those charged with governance (IFAC, 2009). This standard also expatiates on fraud that involves only employees of the entity and refers to it as "employee fraud." In either case, there may be collusion within the entity or with third parties outside of the entity.

According to the Association of certified fraud examiners (ACFE), three main categories of fraud affect organisations and institutions (ACFE, 2008). These are asset misappropriation, corruption and fraudulent statements. Two types of intentional misstatements are relevant to the auditor, (1) misstatements resulting from fraudulent financial reporting and (2) misstatements resulting from misappropriation of assets.

Fraud risk assessment task performance is designated as the focus area for this study because every ministry, department, and agency of government faces a variety of risks from external and internal sources. Furthermore, fraud risk assessment helps auditors determine the nature and extent of audit procedures designed to increase the likelihood of uncovering fraud (Wuerges, 2011; Bloomfield, 1997). Statement of Auditing Standards (SAS) No. 82: Consideration of Fraud in a Financial Statement Audit (AICPA, 1997), the predecessor to SAS No. 99 (AICPA, 2002), also requires documentation of fraud risk. This auditing standard specifies that auditors are to 
document their assessment of fraud risk during the planning phase of the audit and to update the initial assessment as necessary throughout the course of the engagement. Likewise, the SAS No. 99 discusses relevant fraud risk factors that might signal the existence of an intentional material misstatement that is, fraud. The risk factors identified include incentive/pressure, opportunity, and attitude/rationalization. In essence, fraud risk assessment has a direct relationship on the effectiveness of auditors' fraud detection in an audit.

\section{Hypothesis Development Based on Literature Review}

\subsection{Forensic Accountant Knowledge and Auditor Knowledge}

According to Davia (2000), fraud detection, distinct from the financial statement audit, requires a diverse knowledge area and forensic accounting techniques are developed for the primary purpose of detecting, preventing and responding to fraud. Specifically and as a result of (1) an increase in fraud and corruption, (2) the globalization of trade, (3) new and complicated legislation, (4) litigious environment, and (5) the growth in the use of, and sophistication of technology employed in businesses, a forensic accountant specialized knowledge to resolve issues in the court of law will continue to be in hot demand (Ekeigwe, 2011; Davis et al., 2009; Wells, 2005). Prior literature acknowledged the fact that individuals who are knowledgeable in the use of information technology, legal, investigative, criminology, psychology and accounting will perform better in the areas of accounting records, gathering and evaluating financial statement evidence, interviewing all parties related to an alleged fraud situation, and serving as an expert witness in a fraud case (Hopwood, 2008; Rosen, 2006a; Singleton et al., 2006).

In contrast, auditor's knowledge is limited to the nature and scope of audit or task. According to International education standard No. 8, Competence requirements for audit professionals sections $36-41$, auditor's knowledge is classified into three, namely: (1) historical financial information audit at a higher level, (2) financial accounting and reporting at a higher level, and (3) information technology (IFAC-IES, 2006). This study also agrees with Daniel and Lee (2006) that other accountants may look at the charts, but forensic accountants dig deep into the body. Therefore, the following hypothesis is proposed:

H1: Knowledge (forensic accountant and auditor) has a positive direct relationship with Task performance fraud risk assessment (TPFRA).

\subsection{Forensic Accountant Mindset and Auditor Mindset}

A forensic accountant mindset symbolises a unique approach of discerning about accounting records. There is a reason to believe that differences exist between forensic accountant mindset and auditor mindset. While auditors give much thought about the organisation's recorded businesses in terms of the availability, reliability of supporting documentation and an audit trail, they are not duty bound to validate accounting documentation (PCAOB, 2007). Forensic accountants, on the other hand, assume that recorded businesses are not free from fraud in as much as an opportunity and capability for fraud exist in the organisation (Singleton \& Singleton, 2007; Singleton et al., 2006; Wolfe \& Hermanson, 2004).

Strategic planners and intelligence professionals, whose effectiveness depend on overcoming mindsets, face a particular challenge when they work in a bureaucratic or a hierarchical setting such as public sector environment (Feder, 2000). Torelli and Kaikati (2009) saw values as predictors of judgements and behaviours. They postulate that values are abstract representations of the ideal, and, therefore, are more likely to impact behaviour when individuals think abstractly versus concretely; and focus on high versus low level motivations for interpreting their actions. Their empirical findings demonstrated the association between individual mindset and their follow up behaviour especially in task performance.

Mindsets have been a source of government intelligence policy disappointments for decades. As noted by Feder (2000), investigative means for overcoming mindsets also have been long known, but bureaucratic dynamics makes them surprisingly difficult to implement. One of the most promising methods for overcoming mindset is evidence-based multiple scenario analyses. This is best implemented in a loosely structured, networked organization. From the findings of Brand statter and Frank's (2002) study, the inferences arising therefrom are that the implemental mindset is a self-regulatory mechanism that permits a flexible response to the demands of a particular situation This shows clearly that mindsets affect the behaviour of people most especially in the areas of fraud risk assessment task performance. Therefore, the following hypothesis is proposed:

H2: Mindset (forensic accountant and auditor) has a positive direct relationship with Task performance fraud risk assessment (TPFRA). 


\subsection{Differences between Forensic Accountant and Auditor on Knowledge, Mindset and Task Performance Fraud Risk Assessment}

Literature has shown that several commonalities exist between the financial statement auditors and the forensic accountants (Hopwood et al., 2008). It is requisite fundamental principle for the forensic accountants and auditors to uphold a high degree of integrity, objectivity and independence; to be ingenious, to eschew prejudices in all conditions and situations and to possess broad knowledge of accepted accounting principles, business practices and processes (Bologna, 1984).

Although, financial statement auditors and forensic accountants possess similar characteristics; the main difference between the two subject factors lies in their mission. The main goal of any auditor is to "examine whether the company's reported financial statements, taken as a whole, are stated fairly in all material respects in conformity with accepted accounting principles" (Rittenberg et al., 2008) and to "express an opinion on the financial statements of the entity in accordance with the International financial reporting standards and other local standards as appropriate" (IFAC, 2012).

More importantly and on the contrary, the forensic accountants' primary goal is objective verification. This is in line with its professional services as an expert witness for either the prosecution or the defence as forensic accountants can work in both civil and criminal court cases. A successful forensic accountant must be detail oriented, ambitious, persistent and organised. Creativity is significant to forensic accounting profession as most often a forensic accountant must clarify complex financial concepts to an audience that lacks basic accounting experience (Hinders, 2013).

Previous study shows that a simple difference in mindsets can produce considerable performance differences as well as impact persons' confidence, determination, and commitment to accomplish the decision making task (Brandstatter \& Frank, 2002; Gollwitzer et al., 1990; Gollwitzer, 1999). In the context of this study, a forensic accountant mindset differs from an auditor mindset in terms of purpose, frequency, scope, users of services and reports, staffing, limitation to use the report, and objective.

As noted by DiGabriele (2008), any additional difference in knowledge (specialized knowledge) can yield substantial performance differences as well as influence persons' confidence, courage, and commitment to accomplish the decision making task. This position is supported by Davis et al. (2009) in their study of the characteristics, traits and skills of Forensic Accountants.

In the context of this study, forensic accountant knowledge differs from auditor knowledge in terms of identifying crime and criminal intentions because the perpetrators have concealed their activities through a series of complex transactions (Brooks et al., 2005; DiGabriele, 2008). As noted in 2004 by AICPA, the use of forensic accounting procedures to detect financial reporting fraud should be increased. Forensic accountants no doubt play a significant role in government by looking for signs of suspicious financial activity and fraud by persons and businesses, the financial auditors are not expected to look for any symptoms of fraud as they lack the legal system and prosecution procedures. Therefore, it is hypothesized as follows:

H3: Forensic accountants have significant higher levels of the knowledge requirement than auditors.

H4: Forensic accountants have significant higher levels of mindset requirement than auditors.

H5: Forensic accountants have significant higher levels of task performance fraud risk assessment than auditors.

\subsection{Conceptual Framework}

Figure 1 summarizes earlier literature and illustrates the conceptual framework of task performance fraud risk assessment on forensic accountant and auditor knowledge and mindset in the Nigerian public sector. The assessment of fraud risks by utilizing the forensic accountant knowledge and mindset may have a tendency to engender higher task performance than the auditor knowledge and mindset. 


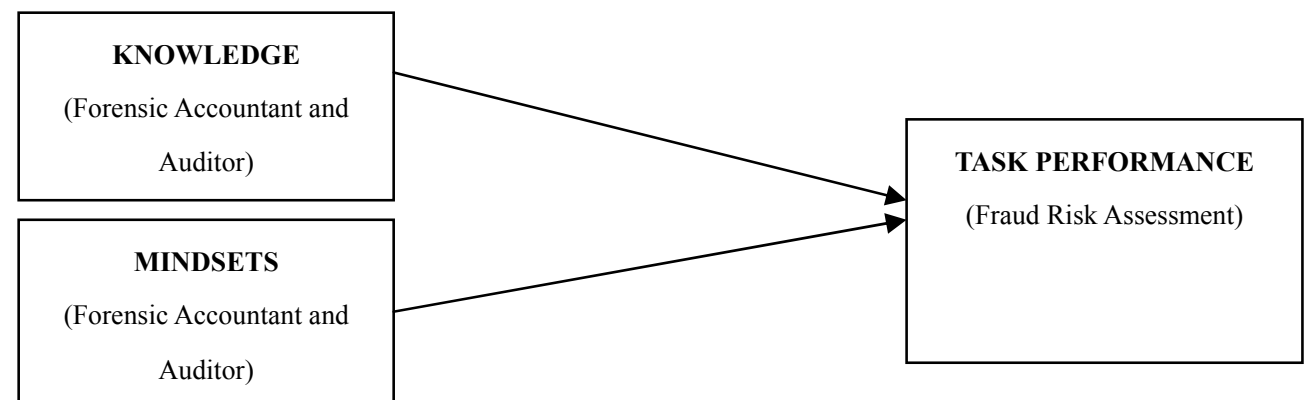

Figure 1. Knowledge and mindset on task performance fraud risk assessment model

\section{Methodology}

This study adopted the positivist ontology, empirical epistemology and quantitative methodology. According to Remenyi et al., (1998), a methodological framework could be derived from a review of the relevant literature, which provides the researcher with a clear expectation of how a particular phenomenon is likely to behave, and from which a researcher formalises a model or paradigm.

Cross-sectional design is employed as data were collected at a single point in time in this study. The meaning of research design is to give credence to the evidence obtained in order for the researcher to answer the research questions as unequivocally as possible (De Vaus, 2011). As noted by Yin (1989), research design deals with "logical problem and not a logistical problem."

The respondents are forensic accountants and auditors in the Nigerian public sector. Prior to the conduct of a pilot study, the survey questionnaire was subject to expert review, comments and suggestions were also considered. Pilot study conducted on 60 respondents, out of which 12 were rejected as unusable. 400 survey questionnaires were distributed on a random sample of accountants and auditors in the office of the Accountant General of the Federation and Auditor General for the Federation. Respondents were asked the extent to which they agreed with statements addressing each of the seven attributes of Knowledge requirement (Davis et al., 2010; Ramaswamy, 2007, 2005) and twenty five attitudes of Mindset requirement (Chui, 2010; Mcleod, 2009) that were used by prior literature. The agreement ratings were made on a 5-point Likert scale ranging from 1 (strongly disagree) to 5 (strongly agree). Furthermore, 12 items on the mindset scale required recoding because they were negatively worded.

Descriptive statistics (ranges, means, and standard deviations) and Mann-Whitney U Test of non-parametric techniques that consider individual observation and random sampling were computed with the use of IBM SPSS Statistics for Windows (Version 20.0). In addition, PLS-SEM a second generation statistical analytical tools was employed for the reflective measurement model (internal consistency reliability - item indicator, composite reliability, the average variance extracted (AVE), discriminant validity) and structural model (path coefficients hypothesis testing and validation, $\mathrm{R}^{2}, \mathrm{f}^{2}$ effect sizes, and predictive relevance $\mathrm{Q}^{2}$ values).

\section{Results}

A total of 267 (66.75\%) individuals completed the survey. 234 (58.5\%) respondents were found to be usable for further analysis whilst $33(8.25 \%)$ were rejected for multiple tickings and non-completion of the survey questionnaire. Of the 234 that were usable, $129(55 \%)$ were forensic accountants and $105(45 \%)$ were auditors. Descriptive statistics for the knowledge, mindset and task performance fraud risk assessment are shown in Table 1 , which include the range, minimum, maximum, mean and the standard deviations.

Table 1. Range, mean and standard deviations of respondents $(n=234)$

\begin{tabular}{lllllll}
\hline & $\mathrm{N}$ & Range & Minimum & Maximum & Mean & Std. Deviation \\
\hline KR_mean & 234 & 1.67 & 3.33 & 5.00 & 4.64 & 0.465 \\
MR_mean & 234 & 1.80 & 3.20 & 5.00 & 4.24 & 0.742 \\
TPFRA_mean & 234 & 2.00 & 3.00 & 5.00 & 4.44 & 0.578 \\
Valid N (listwise) & 234 & & & & & \\
\hline
\end{tabular}


Knowledge construct recorded the highest scores $(\mathrm{M}=4.64, \mathrm{SD}=0.47)$, whilst the lowest score obtained by the mindset construct $(\mathrm{M}=4.24, \mathrm{SD}=0.74)$.

In the evaluation of PLS-SEM results, the author followed in sequence the assessment process of the measurement model (reflective) and the structural model. In the case of reflective measurement model, these include internal consistency (composite reliability), indicator reliability, convergent validity (average variance extracted), and discriminant validity (Hair et al., 2014; Fornell \& Larcker, 1981). In respect of structural model evaluation, coefficient of determination $\left(\mathrm{R}^{2}\right)$, predictive relevance $\left(\mathrm{Q}^{2}\right)$, size and significance of path coefficients, and $\mathrm{f}^{2}$ effect sizes (Hair et al., 2014; Chin, 1998b; Barclay et al., 1995).

According to Hair et al. (2013), the measurement model describes the relationship between the constructs and their corresponding indicator variables (i.e. the outer models in PLS-SEM). In PLS-SEM analysis, there are two major criteria, which are used to assess the measurement model or called "outer model" that include validity and reliability (Ramayah, Lee, \& In, 2011). Reliability test attempts to determine how consistent a measuring instrument measures the concept it is supposed to measure. Validity, on the other hand, tries to find out how well the instrument measures a particular concept it is purposed to measure (Bambale, 2013; Sekaran \& Bougie, 2013; 2010).

As noted by Chin (2010), the old-fashioned parametric-based techniques for significance testing are not appropriate in PLS-SEM as its model does not follow distributional normality assumption of the observations in the procedure for estimating parameters. The bootstrap and the jackknife (algorithm) methods are widely used for evaluating statistical significance in PLS-SEM analysis. While, the bootstrap technique represents a more accurate and exact calculation of measures (Mooney, 1996), the jackknife technique saves resources and reduces execution time for large data sets (Chin, 2010).

In this study, based on the key factor loadings and cross loadings shown in Table 2, all outer loadings of the reflective constructs, KR, MR, and TPFRA are well above the threshold value of 0.708 and hence were all retained. Thus, all of the indicators for the three reflective constructs are well above the minimum acceptable level for outer loadings $0.5\left(0.708^{2}\right)$.

Table 2. Key factor loadings and cross loadings

\begin{tabular}{lllll}
\hline Latent Variable & Indicators & KR & MR & TPFRA \\
\hline Knowledge & KR5 & $\mathbf{0 . 9 1 7}$ & 0.626 & 0.771 \\
& KR6 & $\mathbf{0 . 8 3 3}$ & 0.657 & 0.718 \\
& KR7 & $\mathbf{0 . 8 4 4}$ & 0.610 & 0.655 \\
\hline Mindset & MR1 & 0.570 & $\mathbf{0 . 8 5 5}$ & 0.786 \\
& MR15 & 0.592 & $\mathbf{0 . 8 7 0}$ & 0.737 \\
& MR20 & 0.592 & $\mathbf{0 . 8 8 8}$ & 0.730 \\
& MR23 & 0.771 & $\mathbf{0 . 8 9 1}$ & 0.807 \\
& MR5 & 0.663 & $\mathbf{0 . 9 0 6}$ & 0.806 \\
\hline Task Performance Fraud & TPFRAR1 & 0.795 & 0.783 & $\mathbf{0 . 9 0 5}$ \\
Risk Assessment & TPFRAR2 & 0.785 & 0.749 & $\mathbf{0 . 9 2 0}$ \\
& TPFRAR3 & 0.704 & 0.865 & $\mathbf{0 . 9 0 8}$ \\
& TPFRAR4 & 0.711 & 0.866 & $\mathbf{0 . 8 8 0}$ \\
\hline
\end{tabular}

Also, in the evaluation of the measurement model, Table 2 summarizes the key model quality criteria (convergent validity and reliability analysis) as recommended for PLS-SEM (Hair et al., 2014).

Similarly, the composite reliability (as in Table 3) values of 0.90 (KR), 0.95 (MR), and 0.95 (TPFRA) illustrate that all the three reflective constructs have high levels of internal consistency reliability.

According to Hair, Hult, Ringle, and Sarstedt (2014), convergent validity builds on the AVE value as an evaluation criterion. In this study, the AVE values of KR (0.75), MR (0.78), and TPFRA (0.82) are well above the minimum level of 0.50 . Hence, the measures of the three reflective constructs have a high level of convergent 
validity.

According to Hair, Ringle, \& Sarstedt (2011), if there is any cross loadings that exceed the indicators' outer loadings, this portends a discriminant validity problem. The author checked for discriminant validity problem and found none as all indicators' outer loadings exceeded any of the cross loadings. Considering Table 2, the outer loadings of KR5 (0.917), MR1 (0.855), and TPFRA1 (0.905) show greater loadings than all of their loadings on other constructs (that is, the cross loadings).

Table 3. Model quality criteria: convergent validity and reliability analysis

\begin{tabular}{|c|c|c|c|c|c|c|}
\hline Latent Variable & Indicators & Loadings & $\begin{array}{l}\text { Indicator } \\
\text { Reliability }\end{array}$ & $\begin{array}{l}\text { Composite } \\
\text { Reliability }\end{array}$ & $\mathrm{AVE}^{\mathrm{b}}$ & $\begin{array}{l}\text { Discriminant } \\
\text { Validity? }\end{array}$ \\
\hline \multirow[t]{3}{*}{ Knowledge } & KR5 & 0.917 & 0.841 & 0.90 & 0.75 & Yes \\
\hline & KR6 & 0.833 & 0.694 & & & \\
\hline & KR7 & 0.844 & 0.712 & & & \\
\hline \multirow[t]{5}{*}{ Mindset } & MR1 & 0.855 & 0.731 & & & \\
\hline & MR15 & 0.870 & 0.757 & & & \\
\hline & MR20 & 0.888 & 0.789 & & & \\
\hline & MR23 & 0.891 & 0.794 & 0.95 & 0.78 & Yes \\
\hline & MR5 & 0.906 & 0.821 & & & \\
\hline \multirow{4}{*}{$\begin{array}{l}\text { Task Performance Fraud Risk } \\
\text { Assessment }\end{array}$} & TPFRA1 & 0.905 & 0.819 & & & \\
\hline & TPFRA2 & 0.920 & 0.846 & 0.95 & 0.82 & Yes \\
\hline & TPFRA3 & 0.908 & 0.824 & & & \\
\hline & TPFRA4 & 0.880 & 0.774 & & & \\
\hline
\end{tabular}

Figure 2 shows the pictorial representation of the reflective measurement model of the study.

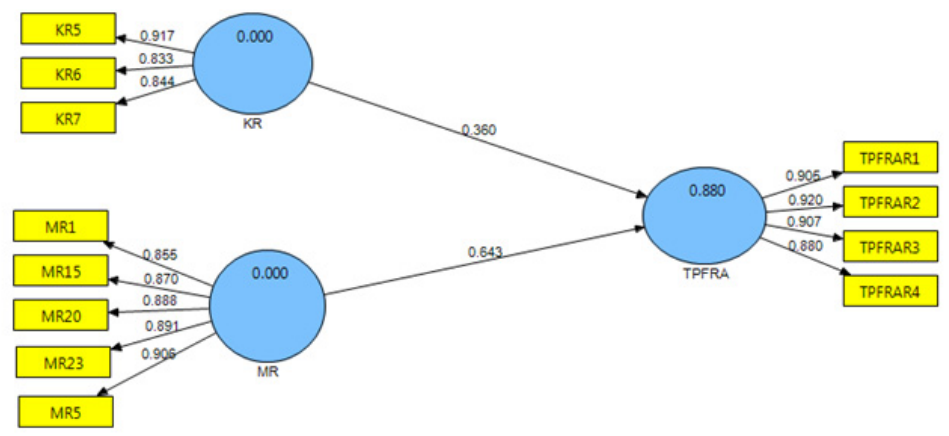

Figure 2. Results of the PLS-SEM algorithm direct effects: KR and MR on TPFRA

Following the presentation of Table 3 and Figure 1, the authors have demonstrated that all the models evaluation criteria have been met, thereby providing rigid support for the measures' reliability and validity in this study.

Prior research confirms that PLS-SEM fits the model to the sample data to obtain the best parameter estimates by maximising the explained variance of the endogenous latent variable(s) (Hair et al., 2014). Following, there are two hypotheses that were formulated to answer the research questions highlighted in chapter 1 of this study. Figure 3 represents the structural model of this study upon which essential criteria for assessment are based. 


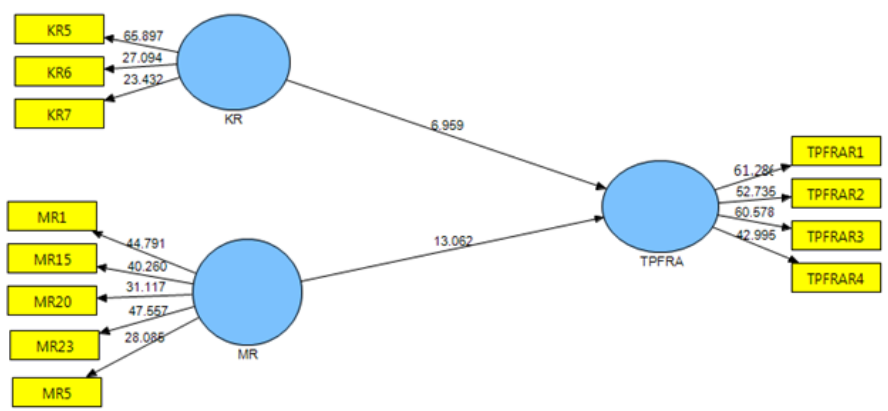

Figure 3. Results of the bootstrapping structural model

\subsection{Evaluating $R^{2}$ of the Model}

The $\mathrm{R}^{2}$ represents the amount of explained variance of the endogenous constructs (that is, task performance fraud risk assessment) in the structural model. Prior research has indicated that a well-developed path model should deliver sufficiently high $\mathrm{R}^{2}$ values to explain certain key constructs such as knowledge and mindset (forensic accountant and auditor). As noted by Chin (2010) and Albers (2010), the baseline for interpreting $\mathrm{R}^{2}$ values of target constructs are 0.25 (weak), 0.50 (medium), and 0.75 (substantial). This study recorded $\mathrm{R}^{2}$ values of 0.88 , which is much higher and visible than the baseline of 0.75 (substantial), thus establishing substantial amount of explained variance in the construct.

\subsection{Evaluating Effect Size $f^{2}$ Values in the Structural Model}

The $\mathrm{f}^{2}$ effect size captures the contribution of each exogenous variable (that is, knowledge and mindset - forensic accountants and auditors) to the $\mathrm{R}^{2}$ value of the target construct of task performance fraud risk assessment in the structural model. The guidelines for evaluating $\mathrm{f}^{2}$ are that values of $0.02,0.15$, and 0.35 respectively represent small, medium, and large effects (Cohen, 1988) of the endogenous latent variable. Table 4 represents the evaluation of $\mathrm{f}^{2}$ effect size on the structural model of this study.

Table 4. Assessing $\mathrm{f}^{2}$ effect sizes of the structural modeltask performance fraud risk assessment (TPFRA)

\begin{tabular}{llllll}
\hline Endogenous Construct & R2incl & R2excl & R2incl-R2excl & 1-R2incl & Effect Size \\
\hline KR & 0.880 & 0.824 & 0.056 & 0.120 & 0.467 \\
MR & 0.880 & 0.790 & 0.090 & 0.120 & 0.750 \\
\hline
\end{tabular}

The task performance fraud risk assessment (endogenous construct) evaluation defines $\mathrm{f}^{2}$ effect size of KR (0.47), and MR (0.75) as belonging to a large effect size, thereby confirming the evaluation criteria to have been met, and, therefore, demonstrated the contribution of each of the exogenous constructs of knowledge and mindset (forensic accountant and auditor) to the target endogenous construct of task performance fraud risk assessment.

\subsection{Evaluating the Predictive Relevance $Q^{2}$ of the Structural Model}

In addition to assessing the degree of the $\mathrm{R}^{2}$ values as a measure of predictive accuracy, the author examines Stone-Geisser's Q2 value (Geisser, 1974; Stone, 1974). This measure is an indicator to show the model's predictive importance. Specifically, when the SEM-PLS exhibits predictive significance, it accurately predicts the data points of indicators in reflective measurement model of endogenous constructs (Hair et al., 2014). Similarly, the $\mathrm{Q}^{2}$ values larger than zero show the path model's predictive relevance for task performance fraud risk assessment. In this study, the $\mathrm{Q}^{2}$ value is obtained by employing the blindfolding procedure for a set distance $\mathrm{D}$ of 7, though a distance figure of 5 to 10 is permissible (Hair et al., 2014). Table 5 represents the assessment of the predictive relevance of $\mathrm{Q}^{2}$ values in the structural model. 
Table 5. Evaluating predictive relevance $\mathrm{q}^{2}$ values in the structural modeltask performance fraud risk assessment (TPFRA)

\begin{tabular}{llllll}
\hline Endogenous Construct & Q2incl & Q2excl & Q2incl-Q2excl & 1-Q2incl & Effect Size \\
\hline KR & 0.712 & 0.662 & 0.050 & 0.288 & 0.17 \\
MR & 0.712 & 0.559 & 0.153 & 0.288 & 0.53 \\
\hline
\end{tabular}

Note. Task Performance Fraud Risk Assessment (TPFRA).

The task performance fraud risk assessment (endogenous construct) evaluation specifies $\mathrm{Q}^{2}$ effect size of KR $(0.17)$, and MR (0.53) as belonging to medium and large effect sizes, thereby confirming the evaluation criteria to have been met, and thus demonstrated the predictive relevance of the endogenous construct to each of the exogenous constructs of knowledge and mindset (forensic accountant and auditor) to the target endogenous construct based on the Cohen's (1988) criteria.

\subsection{Direct Hypothesis}

Two hypotheses were formulated. They are:

H1: Knowledge - forensic accountant and auditor (KR) is positively related to task performance fraud risk assessment (TPFRA).

H2: Mindset - forensic accountant and auditor (MR) is positively related to task performance fraud risk assessment (TPFRA).

Table 6 demonstrates the path coefficient (standardised beta values), the standard error, the $t$ values, the $p$ values of the PLS-SEM structural model and the decision adopted.

Table 6. Direct relationship effects of Knowledge (KR), and Mindset (MR) on task performance fraud risk assessment (TPFRA)

\begin{tabular}{llllll}
\hline No & Hypothesis & Path Coefficient & Standard Error & T Value & Decision \\
\hline 1 & KR -> TPFRA & $0.360^{* *}$ & 0.052 & 6.876 & Support \\
2 & MR -> TPFRA & $0.643 * *$ & 0.050 & 12.892 & Support \\
\hline
\end{tabular}

Note. **Shows the item is significant at the $\mathrm{p}<0.01(1 \%$ level $)$ and * indicates the item is significant at $\mathrm{p}<0.05(5 \%$ level $)$.

This table 6 and Figure 1 indicate direct relationships between knowledge and mindset, and task performance fraud risk assessment and portend three scenarios. First, the result shows that knowledge, as an attribute, maintained significant relationship with task performance fraud risk assessment (competency). In essence, task performance fraud risk assessment in the public sector requires specialised knowledge of forensic accountants and auditors (beta $=0.360 ; \mathrm{t}=6.876 ; \mathrm{p}=0.000$ ). Mindset of forensic accountants and auditors as an attitude enhances the behaviour and reasoning of individuals towards the discharge of their roles with specific emphasis on task performance fraud risk assessment. The results from the PLS-SEM indicates a very strong relationship between mindset and task performance fraud risk assessment ( $b e t a=0.643 ; t=12.892 ; p=0.000$ ).

Most specifically, the results highlights that among the two predictors of TPFRA, mindset (MR) requirement of forensic accountants and auditors recorded the highest significant path coefficient (beta $=0.643$ ). Thus, it shows the significant contribution of MR as the most important predictor of task performance fraud risk assessment by forensic accountants and auditors in the public sector environment. Consequently, the hypotheses - H1 and $\mathrm{H} 2$ are well supported, and, therefore, accepted by this study.

\subsection{Differences between Group Hypotheses (Forensic Accountant and Auditor)}

The author embraced Mann-Whitney U Test to test the hypotheses, which were formulated in answering the research questions identified in chapter 1. Most specifically, there are three hypotheses under consideration. These hypotheses are associated with differences between two independent groups (forensic accountant and auditor) on a continuous measure. The Mann-Whitney U Test explicitly compares medians as against t-test for independent samples that compare means of two groups. Following the comparison of the independent groups, the Mann-Whitney U Test evaluates whether the ranks for the two groups differ significantly (Pallant, 2010; Coakes, 2013). The author explored whether forensic accountants have significant higher levels of knowledge (KR), mindset (MR), and task performance fraud risk assessment (TPFRA) than auditors. Table 7 represents the 
Mann-Whitney U Test for differences between Forensic Accountants and Auditors as hypothesised in 5a - 5c.

The result of the Mann-Whitney U Test revealed a significant difference in the knowledge level of forensic accountants $(\mathrm{Md}=5, \mathrm{n}=129)$ and auditors $(\mathrm{Md}=4, \mathrm{n}=105), \mathrm{U}=1796.000, \mathrm{z}=-10.893, \mathrm{p}=.000, \mathrm{r}=.7$; mindset level of forensic accountants $(\mathrm{Md}=5, \mathrm{n}=129)$ and auditors $(\mathrm{Md}=3.4, \mathrm{n}=105), \mathrm{U}=0.000, \mathrm{z}=-13.756$, $\mathrm{p}=.000, \mathrm{r}=.9)$ and task performance fraud risk assessment level of forensic accountants $(\mathrm{Md}=5, \mathrm{n}=129)$ and auditors $(\mathrm{Md}=3.75, \mathrm{n}=105), \mathrm{U}=245.000, \mathrm{z}=-13.370, \mathrm{p}=.000, \mathrm{r}=.9$ ).

The results showed that forensic accountants possess higher levels of knowledge, mindset and task performance fraud risk assessment than auditors in the areas of fraud detection, prevention/deterrent and response since the effect size " $r$ " of the constructs are higher than 0.5 , which symbolizes the large significant effect size based on Cohen's (1988) criteria.

Table 7. Summary of the differences hypotheses between forensic accountants and auditors

\begin{tabular}{|c|c|c|c|c|c|c|c|c|}
\hline & & & & & t Statistics & & Means & \\
\hline $\begin{array}{c}\text { Hypothesis } \\
\text { No. }\end{array}$ & Latent Variable & $\begin{array}{c}\text { Role to Forensic } \\
\text { Accounting }\end{array}$ & $\mathrm{N}$ & $\begin{array}{c}\text { Mann-Whitney U } \\
\text { Test } \\
\end{array}$ & Z-Score & $\begin{array}{c}\text { Asymp. Sig. } \\
\text { (2-tailed) }\end{array}$ & Median & Decision \\
\hline \multirow{3}{*}{3} & \multirow{3}{*}{ Knowledge } & $1 \mathrm{FA}$ & 129 & & & & 5.00 & \\
\hline & & 2 Auditor & 105 & 1796.000 & -10.893 & .000 & 4.00 & Support \\
\hline & & Total & 234 & & & & 5.00 & \\
\hline \multirow{3}{*}{4} & \multirow{3}{*}{ Mindset } & $1 \mathrm{FA}$ & 129 & & & & 5.00 & \\
\hline & & 2 Auditor & 105 & & & & 3.40 & Support \\
\hline & & Total & 234 & 0.000 & -13.756 & .000 & 4.40 & \\
\hline \multirow{3}{*}{5} & Task Performance & $1 \mathrm{FA}$ & 129 & & & & 5.00 & \\
\hline & Fraud Risk & 2 Auditor & 105 & & & & 3.75 & Support \\
\hline & Assessment & Total & 234 & 245.000 & -13.370 & .000 & 4.75 & \\
\hline
\end{tabular}

Accordingly, Table 7 and Figures 2 demonstrate the key summary of the findings and confirm the results of the three Hypotheses (H3, H4 and H5), which states forensic accountants possess significant higher levels of knowledge, mindset, and task performance fraud risk assessment than auditors. In essence, hypotheses H3, H4 and $\mathrm{H} 5$ of this study, having been tested are supported empirically.

Note: The effect size statistic (r) is calculated by using the $\mathrm{z}$ value reported in the output, and this is illustrated thus: $\mathrm{r}=\mathrm{z}$ / square root of $\mathrm{N}$, where $\mathrm{N}=$ total number of cases.

Table 8 . Summary of results of hypotheses testing

\begin{tabular}{lll}
\hline No & Hypotheses & Result \\
\hline H1 & Kirect effect on task performance fraud risk assessment & \\
& related to task performance fraud risk assessment (TPFRA). & Supported \\
H2 & Mindset - forensic accountant and auditor (MR) is positively & Supported \\
& related to task performance fraud risk assessment (TPFRA). & \\
\hline H3 & Differences between groups - Forensic accountants and Auditors & \\
& Forensic accountants have significant higher levels of knowledge (KR) & Supported \\
H4 & requirement than auditors. & \\
& Forensic accountants have significant higher levels of mindset (MR) & Supported \\
& requirement than auditors. & \\
H5 & Forensic accountants have significant higher levels of task & Supported \\
& performance fraud risk assessment (TPFRA) requirement than auditors. & \\
\hline
\end{tabular}




\section{Discussions}

In this study, task performance fraud risk assessment (TPFRA) denotes the forensic accountant and auditor's ability to assess the risk of fraud to a "defined standard in the real working environment." With respect to knowledge (KR), mindset (MR) and TPFRA of the accounting and auditing organisations, this study found that knowledge, and mindset have significant relationships with task performance fraud risk assessment.

Knowledge in this study refers to the forensic accountant and the auditor's attribute and proficiency competences necessary and relevant to discharge technical and innovative task, especially with respect to identifying and analysing methods and procedures for fraud prevention, detection and response from the Nigerian public sector environment (Popoola et al., 2013a; Popoola et al., 2013b; Davis, Farrell \& Ogilby, 2010; Ramaswamy, 2007; 2005). Hypothesis $\mathrm{H} 1$ of this study states that Knowledge-forensic accountant and auditor (KR) is positively related to task performance fraud risk assessment (TPFRA). As expected, the finding provides support for the hypothesis. Importantly and in this context, the current findings significantly agree with the previous research (Wuerges, 2011; Davis, Farrell \& Ogilby, 2010; Ramaswamy, 2007; 2005) that found a positive relationship. It clearly shows that as forensic accountant and auditor acquire more knowledge in relation to fraud detection, prevention and response, the individual level of fraud risk assessment task performance increases. The result in knowledge development would correspondingly increase their proficiency competences; create awareness and understanding of the fraud schemes.

Mindset (MR) refers to the forensic accountant and auditor's attitude towards competent performance in the workplace. Mindset is the positive mental attitude of a forensic accountant and auditor to prevent, detect and response to fraud (Popoola et al., 2013b; Wuerges, 2011; Chui, 2010; Singleton \& Singleton, 2007). Hypothesis H2 of this study states that Mindset-forensic accountant and auditor (MR) is positively related to task performance fraud risk assessment (TPFRA). As expected, the finding provides support for the hypothesis. Importantly and in this context, the current findings significantly agree with the previous research (Wuerges, 2011; Chui, 2010; Frank, 2010; Boritz et al., 2008; Singleton et al., 2006) that found a positive relationship.

Davis, Farrell and Ogilby (2010) also agreed on this attribute of competences for the forensic accountant in workplace. On the other hand, auditor's knowledge consists of historical financial information audit at a higher level, financial accounting and reporting at a higher level and information technology (IFAC IES, 2006).

The hypothesis $\mathrm{H} 3$ states that forensic accountants have significant higher levels of knowledge (KR) requirement than auditors. As expected, the finding provides support for the hypothesis. Importantly and in this context, the current findings significantly agree with the previous research (Wuerges, 2011; Davis, Farrell \& Ogilby, 2010; Ramaswamy, 2007; 2005) that found a positive relationship. This clearly shows that forensic accountants have significant higher levels of knowledge (KR) requirement than auditors in the area of fraud detection, prevention and response.

In this study, mindset is defined as a positive mental attitude which influences individual's (forensic accountant and auditor) cognitive behaviour in the workplace. The hypothesis $\mathrm{H} 4$ states that forensic accountants have significant higher levels of mindset (MR) requirement than auditors. As expected, the finding provides support for the hypothesis. Importantly and in this context, the current findings significantly agree with the previous research (Wuerges, 2011; Chui, 2010; Frank, 2010; Boritz et al., 2008; Singleton et al., 2006) that found forensic accountants to have higher levels of mindset requirement than auditors. This clearly shows that forensic accountants have significant higher levels of mindset (MR) requirement than auditors in the areas of fraud detection, prevention and response.

Task performance fraud risk assessment is the bedrock of the audit assignment. It does not only indicates the direction of the audit, but assists forensic accountants and auditors to ascertain the organisation's environment and scope of audit procedures, which are planned to identify the possibility and importance of fraud (Wuerges, 2011; Chui, 2010). The hypothesis H5 states that forensic accountants have significant higher levels of task performance fraud risk assessment (TPFRA) requirement than auditors. As expected, the finding engenders support for the hypothesis.

Importantly, the current findings significantly agree with the previous study (FRC, 2014; Owens, 2012; Wuerges, 2011; Chui, 2010; IFAC, 2009; PCAOB, 2008; ICAN, 2005; Wilks\&Zimbelman, 2004; Knapp \& Knapp, 2001; Hackenbrack, 1992) that found forensic accountants to have higher levels of task performance fraud risk assessment requirement than auditors. 


\section{Conclusion}

This study supports the concern that no nation is immune to fraud. Fraud is costly and damages the reputation of the accounting profession every day. The impact of fraud in relation to the provision of infrastructure, facilities and public services is alarming and untenable.

The first limitation of this present research is about fraud and corrupt practices in a developing country, Nigeria with over 165 million people. Examining the mediating influence of fraud related problem representation on knowledge, and mindset (forensic accountant and auditor) and task performance fraud risk assessment in the public sector could be considered as sensitive and thus raise the issue of such bias.

The next limitation of this study has to do with the adoption of cross-sectional design in which data are collected at one point of time (i.e., within August to November 2013); there is no time to wait for different follow-up stages or interventions before data analysis. Notwithstanding the usefulness and popularity of this design, there are challenges. One of which is related to change over time of studied variables (i.e., knowledge, mindset and task performance fraud risk assessment).

Future research in this area could include professional values. Value signpost what constitutes normative behaviours, as well as acceptable roles for the individual within particular social contexts (Bambale, 2013; Triandis, 1995). In essence, values (forensic accountant and auditor) can serve as moderator in a model involving knowledge, mindset (forensic accountant and auditor), and task performance fraud risk assessment. Specifically, values can be tested as a moderator on the relationship between knowledge, and mindset (forensic accountant and auditor) and task performance fraud risk assessment.

Importantly, as government activities grow in size and complexity, acquisition and deployment of information technology and management override of the internal controls; there would be no end to fraud challenges and demand for forensic accountants.

\section{References}

Adams, R. A. (2004). Public Sector Accounting and Finance Made Simple (3rd ed.).

Adebisi, F. A. (2011). Audit, Investigation and Forensics: Similarities and Differences. Institute of Chartered Accountants of Nigeria: Forensic, Audit \& Investigation Faculty, February.

AICPA. (1997). Statement on Auditing Standards (SAS) No. 82: Consideration of Fraud in a Financial Statement Audit (American Institute of Certified Public Accountants, Durham).

AICPA. (2002). American Institute of Certified Public Accountants.Statement on Auditing Standards (SAS) No. 99, Consideration of Fraud in a Financial Statement Audit (AICPA, Professional Standards, vol. 1, AU Sec. 316.50).

Albers, S. (2010). PLS and success factor studies in marketing. In Esposito Vinzi, V., Chin, W. W., Henseler, J., Wang, H. (Eds.), Handbook of Partial Least Squares: Concepts, Methods and Applications (Springer Handbooks of Computational Statistics Series, vol. II, pp. 409-425). Springer, Heidelberg, Dordrecht, London, New York.

Asare, S. K., \& Wright, A. M. (2004). The Effectiveness of Alternative Risk Assessment and Program Planning Tools in a Fraud Setting. Contemporary Accounting Research, 21(2), 325-352.

Bambale, A. J. (2013). The mediating effect of psychological ownership on the relationship between servant leadership and organizational citizenship behaviours in Kano, Nigeria. A thesis submitted to the Othman Yeop Abdullah Graduate School of Business, Universiti Utara Malaysia, in fulfilment of the requirement for the Degree of Doctor of Philosophy. Malaysia.

Bammeke, S. A. (2008). Public Sector Accounting and Finance for Decision Making. Lagos, Sab \& Associates Limited.

Barclay, D., Higgins, C., \& Thompson, R. (1995). The partial least squares (PLS) approach to causal modeling. Technology Studies, 2, 285-323.

Baron, L. (2006). CPAs Are a Hot Commodity.Journal of Accountancy, 201(2).

Bloomfield, R. J. (1997). Strategic Dependence and the Assessment of Fraud Risk: A Laboratory Study.The Accounting Review, 72(4), 517-538.

Boleigha, P. (2011). Meaning of Forensic. Institute of Chartered Accountants of Nigeria: Forensic Audit \& Investigation Faculty. 
Boritz, J. E., Kotchetova, N., \& Robinson, L. A. (2008). Planning Fraud Detection Procedures: Fraud Specialists vs. Auditors. Working Paper: University of Waterloo.

Brandstatter, V., \& Frank, E. (2002). Effects of Deliberative and Implemental Mindsets on Persistence in Goal-directed Behaviour. Personality and Social Psychology Bulletin, 28(10), 1366-1378.

Brooks, R. C., Riley Jr, R. A., \& Thomas, J. (2005). Detecting and preventing the financing of terrorist activities: A role for government accountants. The Journal of Government Financial Management, 54(1), 12-18.

Chin, W. W. (1998b). The partial least squares approach for structural equation modeling. In George A. Marcoulides (Ed.), Modern Methods for Business Research (pp. 295-336). Lawrence Erlbaum Associates, Lawrence Erlbaum Associates, Mahwah, NJ.

Chin, W. W. (2010). How to write up and report PLS analyses. In Esposito et al. (Eds.), Handbook of Partial Least Squares (pp. 655-688). New York: Springer-Verlag.

Chui, L. (2010). An experimental examination of the effects of fraud specialist and audit mindsets on fraud risk assessments and on the development of fraud-related problem representation. Pro Quest LLC, UMI 3436520 , 789 East Eisenhower Parkway, USA.

Coakes, S. J. (2013). SPSS: Analysis without anguish: version 20.0 for Windows. John Wiley \& Sons Australia, Ltd. Milton, Qld 4064.

COCO. (2011). Committee of Sponsoring Organizations of the Treadway Commission (COSO). Internal Control Framework.

Cohen, J. (1988). Statistical Power Analysis for the Behavioural Sciences (2nd ed.). Lawrence Erlbaum Associates, Hillsdale, NJ.

Cohen, M. M., Crain, M. A., \& Sanders, A. (1996). Skills Used in Litigation Services. Journal of Accountancy, $182,101-104$.

Cressey, D. R. (1950). The criminal violation of financial trust.American Sociological Review, 15(6), 738-743.

Cressey, D. R. (1953). Other People's Money: A study in the Social Psychology of Embezzlement. Glencoe, IN: Free Press.

Daniel, A., \& Lee, B. (2006). Forensic Accountants appearing in the Literature. Retrieved March 10, 2012 from http://www.bus.lsu.edu/accounting/faculty/lcrumbley/forensic.html

Daniel, G. I. (1999). Public Sector Accounting. Ahmadu Bello University Press, Zaria, Kaduna.

Davia, H. R. (2000). Fraud 101: Techniques and Strategies for Detection. New York, NY: John Wily and Sons, Inc.

Davis, C., Farrell, N., \& Ogilby, S. (2010). Characteristics and skills of the Forensic Accountant. American Institute of certified Public Accountants FVS section

De Vaus, D. A. (2011). Research Design in Social Research. London: Sage Publications Ltd.

DiGabriele, J. A. (2008). An Empirical Investigation of the Relevant Skills of Forensic Accountants.Journal of Education for Business, 331-338.

Doering, J. (2002). Sarbanes-Oxley Act.

Ekeigwe, C. C. (2011). Skill sets for Forensic Accountant. Institute of Chartered Accountants of Nigeria: Forensic Audit \& Investigation Faculty.

Feder, S. A. (2000). Overcoming "mindsets": What corporations can learn from government intelligence failures? Competitive Intelligence Review, 11(3), 28-36.

Fornell, C., \& Larcker, D. F. (1981). Evaluating structural equation models with unobservable and measurement error. Journal of Marketing Research, 18, 39-50.

FRC. (2014). Audit Quality Thematic Review: Fraud risks and laws and regulations. The Financial Reporting Council Limited (p. 6). Aldwych, London.

Geisser, S. (1974). A predictive approach to the random effects model. Biometrika, 61, 101-107.

Gollwitzer, P. M. (1999). Implementation intentions: strong effects of simple plans. American Psychologist, 54(7), 493.

Gollwitzer, P. M., Heckhausen, H., \& Steller, B. (1990). Deliberative and implemental mind-sets: Cognitive 
tuning toward congruous thoughts and information. Journal of Personality and Social Psychology, 59(6), 1119.

Hackenbrack, K. (1992). Implications of Seemingly Irrelevant Evidence in Audit Judgment.Journal of Accounting Research (Spring), 54-76.

Hair, J. F., Hult, G. T. M., Ringle, C. M., \& Sarstedt, M. (2013). A Primer on Partial Least Squares Structural Equation Modeling. Sage, Thousand Oaks.

Hair, J. F., Hult, G. T. M., Ringle, C. M., \& Sarstedt, M. (2014). A Primer on Partial Least Squares Structural Equation Modeling (PLS-SEM). Sage, Thousand Oaks.

Hair, J. F., Ringle, C. M., \& Sarstedt, M. (2011). PLS-SEM: Indeed a silver bullet. Journal of Marketing Theory and Practice, 19(2), 139-151.

Harris, C. K., \& Brown, A. M. (2000). The Qualities of a Forensic Accountant. Pennsylvania CPA Journal, 71, $2-3$.

Hassan, M. M. (2001). Government Accounting. Malthouse Press Limited, Lagos, Nigeria.

Hopwood, W. S., Leiner, J., \& Young, G. R. (2008). Forensic Accounting. New York, NY: McGraw-Hill/Irwin. Retrieved from http://www.acfe.com/about/press-release.asp?copy=10-12-2005

ICAN. (2005). Nigerian Standards on Auditing (NSA) No. 5: The Auditor's responsibility to Consider fraud in an Audit of financial statements. Institute of Chartered Accountants of Nigeria (ICAN). Lagos, Nigeria

ICAN. (2009). The Institute of Chartered Accountants of Nigeria Public Sector Accounting Study Pack. VI Publishers, Lagos, Nigeria.

IFAC. (2005). International Standard on Auditing (ISA) 240: The Auditor's Responsibility to Consider Fraud in an Audit of Financial Statements. Handbook of International Auditing, Assurance, and Ethics Pronouncements. International Federation of Accountants. New York.

IFAC. (2006). International Accounting Education Standard Board (IES 8, 2006). Competence Requirements for Audit Professionals. International Federation of Accountants.

IFAC. (2006). International Framework for Assurance Engagements.

IFAC. (2009). International Standard on Auditing (ISA) No. 700: Forming an Opinion and Reporting on Financial Statements.

IFAC. (2009). International Standard on Auditing (ISA) No. 200: Overall Objectives of the Independent Auditor and the Conduct of an Audit in Accordance with International Standards on Auditing.

IFAC. (2009). International Standard on Auditing (ISA) No. 240 Revised: The Auditor's Responsibility to Consider Fraud in an Audit of Financial Statements. Handbook of International Auditing, Assurance, and Ethics Pronouncements. International Federation of Accountants.New York.

Johnson, E. I. (1996). Public Sector Accounting and Financial Control (2nd ed.). Surulere, Lagos: Financial Training Centre.

Knapp, C. A., \& Knapp, M. C. (2001). The Effects of Experience and Explicit Fraud Risk Assessment in Detecting Fraud with Analytical Procedures. Accounting, Organizations and Society, 26, $25-37$.

McLeod, S. A. (2009). Attitude measurement. Retrieved on 4th January, 2013 from Retrieved from http://www.simplypsychology.org/attitude-measurement.html

Messier, W. F., Glover, S. M., \& Prawitt, D. F. (2006). Auditing \& Assurance Services: A Systematic Approach. Issues in Accounting Education, 21(3), 330.

Messmer, M. (2004). Exploring Options in Forensic Accounting. National Public Accountant, 5, 9-20.

Mooney, C. (1996). Bootstrap statistical inference: Examples and evaluations for political science. American Journal of Political Science, 40(2), 570-602.

Owojori, A. A., \& Asaolu, T. O. (2009). The role of forensic accounting in solving the vexed problem of the corporate world. European Journal of Scientific Research, 29(2), 183-187.

Pallant, J. (2010). SPSS Survival Manual: A step by step guide to data analysis using SPSS (4th ed.).McGraw Hill.

PCAOB. (2007). Audit Evidence. AU Section 326. Public Company Accounting Oversight Board. 
PCAOB. (2008). Public Company Accounting Oversight Board. Standing Advisory Group. Retrieved December 2, 2008, from http://www.pcaobus.org/Standards/Standing_Advisory_Group/index.aspx

Popoola, O. M. J., Ahmad, A., \& Samsudin, R. S. (2013a). Forensic accounting knowledge and skills on task performance fraud risk assessment: Nigerian public sector experience. Conference proceedings. Okinawa, Japan.

Popoola, O. M. J., Ahmad, A., Samsudin, R. S., \& Ahmad, H. (2013b). Task performance fraud risk assessment on forensic accountant knowledge and mindset in Nigerian public sector. Conference procedings. Seoul, South Korea.

Ramaswamy, V. (2005). Corporate Governance and the Forensic Accountant. The CPA Journal, 75, 69-70.

Ramaswamy, V. (2007). New Frontiers: Training Forensic Accountants within The Accounting Program. Journal of College Teaching \& Learning, 4(9).

Ramayah, T., Lee, J. W. C. \& In, J. B. C. (2011). Network collaboration and performance in the tourism sector. Service Business, 5, 411-428.

Remenyi, D., Williams, B., Money, A., \& Swartz, E. (1998).Doing research in business and management: An introduction to process and method. London: Sage Publication.

Rezaee, Z., Crumbley, D., \& Elmore, R. (2004). Forensic Accounting Education: A Survey of Academicians and Practitioners. Advances in Accounting Education Teaching and Curriculum Development, 6, 193.

Rosen, L. S. (2006a). CAP Forum on Forensic Accounting in the Post-Enron World Forensic Accounting: Where and When Headed? Canadian Accounting Perspectives, 5(2), 257-264.

Sekaran, U., \& Bougie, R. (2010). Research Methods for Business: A Skill Building Approach (5th ed.) John Wiley \& Sons, Ltd, Publication.

Sekaran, U., \& Bougie, R. (2013). Research Methods for Business: A Skill Building Approach (6th ed.). John Wiley \& Sons, Ltd, Publication.

Sickinger, T. (1995). Ex-con Artist Helps Find Fraud. The Kansas City Star. P. B1. October 18,

Singleton, T. W., \& Singleton, A. J. (2007). Why Don't We Detect more Fraud? Journal of Corporate Accounting and Finance, 18(4), 7-10.

Singleton, T. W., Singleton, A. J., Bologna, G. J., \& Lindquist, R. J. (2006). Fraud Auditing and Forensic Accounting (3rd ed.). Hoboken, NJ: John Wiley and Sons, Inc.

Stone, M. (1974). Cross-validatory choice and assessment of statistical predictions. Journal of the Royal Statistical Society, 36, 111-147.

Torelli, C. J., \& Kaikati, A. M. (2009). Values as predictors of judgments and behaviours: The role of abstract and concrete mindsets. Journal of Personality and Social Psychology, 96(1), 231.

Triandis, H. C. (1995). Individualism and collectivism. Boulder, CO: Westview Press

Wells, J. (2003). The Fraud Examiners: Sleuthing Careers Bring CPAs Personal and Professional Satisfaction. Journal of Accountancy, 196(4).

Wells, J. T. (2005). Accountants need help fighting the war on fraud; ACFE founder urges antifraud education. Retrieved November 13, 2012 from the Association of Certified Fraud Examiner. http://wwwacfe.om/about/press-release.asp?cpy=10-12-2005.

Wilks, T. J., \& Zimbelman, M. F. (2004). Decomposition of Fraud-Risk Assessments and Auditors' Sensitivity to Fraud Cues. Contemporary Accounting Research, 21(3), 719-745.

Wolfe, D. T., \& Hermanson, D. R. (2004). The Fraud Diamond: Considering the Four Elements of Fraud. The CPA Journal, 74(12), 38-42.

Wuerges, A. (2011). Auditors' Responsibility for Fraud Detection: New Wine in Old Bottles? Retrieved on November 3, 2012 from http://www.scribd.com/doc/63671899/Auditors-Responsibility-for-Fraud-Detection

Yin, R. K. (1989). Case Study research: design and methods (Vol. 5). Newbury Park, CA. Sage Publications. 


\section{Copyrights}

Copyright for this articleis retained by the author(s), with first publication rights granted to the journal.

This is an open-access article distributed under the terms and conditions of the CreativeCommons Attribution license (http://creativecommons.org/licenses/by/3.0/). 